\title{
A cabeça calva de Deus, de Corsino Fortes: uma trilogia épica cabo-verdiana e universal
}

\section{A cabeça calva de Deus, by Corsino Fortes: an epic and universal Cape Verdean trilogy}

\author{
Christina RAmalho*
}

ançada por Publicações Dom Quixote, em 2001, A cabeça calva de Deus, do cabo-verdiano Corsino Fortes, reúne três poemas longos: Pão \& Fonema (1974), Árvore \& Tambor (1986) e Pedras de Sol \& Substancia (2001). O metafórico título - A cabeça calva de Deus -, unindo os três poemas, reitera a intenção do autor, visível tanto na estrutura das composições quanto em seu teor, de compor um painel épico de sua nação.

O fato de o poeta ter produzido sua obra em partes justifica-se sem dificuldade. Pão \& Fonema, Árvore \& Tambor e Pedras de Sol \& Substância refletem marcos históricos e temporais diferentes para uma nação que somente em 1975 alcançou a independência. Se a primeira parte terá como amálgama uma forte experiência de luta, uma vez que o autor esteve diretamente envolvido com o movimento intelectual que defendia a libertação de Cabo Verde do colonialismo português e foi militante do P.A.I.G.C.; a segunda parte, Árvore \& Tambor, refletirá outra consciência da terra, desta vez mais calcada no que Ana Mafalda Leite, que prefaciou a obra, chamou de "reinvenção da terra caboverdiana" (Apud: FORTES, 1986, p. 11). Já Pedras de Sol \& Substância, atravessando a fronteira do século XX, revisita a questão da identidade nacional, perpassando as camadas míticas dessa cultura, as tradições culturais, e determinados vieses políticos de recente história como nação. Por essa razão,

* Universidade Federal de Sergipe, Aracaju, Sergipe, Brasil. E-mail: ramalhochris@hotmail.com. 
era necessário que décadas fossem atravessadas até que Corsino Fortes tivesse em mãos um repertório significativo de expectativas e realizações associadas à realidade nacional, para que, com elas, pudesse compor um painel épico suficientemente amplo de sua pátria.

Os três poemas, juntos, somam 4.055 versos, com divisões internas nomeadas como cantos. É visível o fio épico que une as partes da obra, compondo uma grande narrativa lírica. Além disso, também nela se destaca a densidade do trabalho com a linguagem, que inclui poemas em crioulo, e que se caracteriza pela concisão, pelo ritmo construído pela musicalidade das assonâncias, pela repetição multissignificativa de sememas como ilha, mar, milho, povo, mulher, cabra, sol, árvore, tambor e palavra, e pela presença de um eu lírico/ narrador que se assume como parte integrante do universo retratado.

A cada um dos sememas que reaparece, a construção poética agrega valores, associando-os a um campo próprio de imagens, cuja função é reafirmar a identidade cultural do país. A confluência plural desses símbolos gera outro, mais amplo, o "ovo", denunciando a visão cosmogônica impressa na obra, que faz de Cabo Verde um microcosmo metonímico que reflete o estar no mundo universal.

O eu-lírico/narrador ora é personagem principal de uma sucessão de eventos, ora é espectador e valorizador de ações alheias, ora é vaticinador, ora é revisor crítico de registros históricos e culturais. Do trabalho com a linguagem figurada à preocupação de, através do espaço dado à língua crioula na poesia, reafirmar outra face da identidade nacional, o que se recolhe é uma consciência lírica densa, ciente de seus recursos de criação e de sua função social como poeta.

Corsino Fortes, homem de invejável carreira como político, administrador e literato, sempre esteve em sintonia fina com as manifestações artísticas de seu tempo, o que se evidencia na atualidade de sua obra, na preocupação estética, e no diálogo com culturas alheias e afins, como as africanas e a brasileira. Oriundo da geração dos claridosos ${ }^{1}$, Fortes materializou, com a palavra poética, uma vivência profunda do significado de "ser cabo-verdiano".

Pão \& Fonema inicia-se com "Proposição" e é desenvolvido em três cantos ("Tchon de pove tchon de pedra"; "Mar \& Matrimónio"; "Pão \& Património”). A grande marcação temporal em Pão \& Fonema é o "agora”, transcrito em maiúsculas no poema "Do nó de ser ao ônus de crescer", que abre o

\footnotetext{
* Geração assim nomeada pela participação de artistas e intelectuais na Revista Claridade (1936-1960).
} 
Canto Terceiro: AGORA POVO AGORA (2001, p. 75), o que define a "urgência" de Pão \& Fonema e seu vínculo com a atitude de quem se prepara para um tempo novo: o da independência.

Árvore \& Tambor apresenta uma abertura intitulada "Proposição \& Prólogo", seguida por cinco cantos. Ao final, há uma nova parte, intitulada "Prólogo \& Proposição", o que faz a leitura desdobrar-se e, de forma circular, voltar ao início de Arvore \& Tambor, para estabelecer uma comparação entre as duas partes. O poema também alude à "hora zero", a do nascimento da pátria. O passado se recompõe em fragmentos de alto teor crítico, em que figuras ímpares, como a de Agostinho Neto, são retomadas como ícones de uma atitude positiva de enfrentamento da realidade e simultâneo trabalho com a linguagem em prol de uma real experiência de libertação e liberdade.

Pedras de Sol \&o Substância tem início com "Oráculo" e se desenvolve em três cantos. O plano histórico também se apresenta fragmentado, embora, ao mesmo tempo, reintegre as perspectivas da origem imemorial, do período que marca a transição de Colônia para República, e o futuro da pátria "Recém-nascida!” (2001, p. 289). O que se percebe nessa parte da obra é o destaque à dimensão cotidiana no tempo. Há, por exemplo, no Canto Segundo, em "Litografias para as festas de São Filipe. Segundo Manuel Figueira e Luísa Queirós Figueira", uma série de poemas em que cada um recebe como título o nome de um dia da semana. Extraindo das telas dos artistas o motivo para os poemas, Corsino capta, simultaneamente, o tempo e o espaço cotidianos.

O plano histórico, nos três poemas, alude aos cabo-verdianos ilustres e comuns, a características marcantes do cotidiano insular, tais como as práticas econômicas derivadas da geografia das ilhas (a pesca, a cultura do milho), às relações familiares e pessoais muitas vezes determinadas pela vivência da diáspora (e algumas vezes do exílio), e às representações do humano oriundas das relações entre realidade e utopia, visto que o imaginário do país, por sua secular condição de colônia, transitou por veredas marcadas pela diversidade que caracteriza a formação do povo.

O plano maravilhoso, igualmente fragmentado, é representado pelo somatório de imagens míticas relacionadas ao tempo imemorial do surgimento da terra e, principalmente, da palavra cabo-verdiana, aqui entendida como real possibilidade de voz e expressão. Apesar de Cabo Verde ter sido habitado a partir da chegada dos portugueses, imagens míticas como a da rotcha scribida 
(com traços rupestres que indicam uma presença ancestral nas ilhas) denunciam o desejo de transgredir o registro histórico em busca de um "si-mesmo" pautado por outra lógica que não aquela que, convencionalmente, organiza o sentido da distribuição da presença humana nos continentes.

O heroísmo em $A$ cabeça calva de Deus tem várias faces: são as mulheres que ficaram na terra, semeando no campo árido a continuidade de sua pátria; são as crianças, incluindo aquelas que vivem nas ruas; são as figuras mais ilustres de artistas, literatos, ativistas políticos, educadores, entre outros; são os companheiros de luta do eu-lírico/narrador, que não só os nomeia como os instiga a continuar a luta; são trabalhadores; são as gentes antigas e os antepassados imemoriais, que, somados, dão vida humana à terra feita de pedra vulcânica. E a esse grupo se une o próprio eu-lírico/narrador, que, em muitos trechos se revela, revelando sua família, seus laços de afeto e afinidade.

A matéria épica do poema, enfim, pode ser definida como a formação mítico-histórica da nação cabo-verdiana, considerados aí aspectos marcantes dessa identidade: a fragmentação de seu território insular, as sobredeterminações climáticas e geográficas que dão ao signo seca e ao signo chuva potencial semântico intenso; as injunções colonialistas que delinearam conjunturas econômicas e políticas às vezes desastrosas; a mestiçagem na formação da identidade nacional; a arte como forma de enfrentamento do cotidiano; entre outros.

De grande beleza estética e sofisticada construção de sentido, a obra é um marco na história da literatura cabo-verdiana e fonte constante de referência em produções de outros/as escritores/as do país. Além disso, logrou, como realização literária, atravessar fronteiras, ter trechos vertidos em outros idiomas e merecer diversas considerações críticas. Ler a obra é vivenciar, simultaneamente, o prazer do texto literário e a fruição de uma cultura que atravessa a palavra e se faz imagem reluzente.

\section{Referências bibliográficas}

FORTES, Corsino. A cabeça calva de Deus. Lisboa: Publicações Dom Quixote, 2001. Arvore \& Tambor. Praia: Instituto Caboverdiano do Livro; Lisboa: Publicações Dom Quixote, 1986.

Recebido em 18 de junho e aprovado em 10 de outubro de 2012. 